\title{
International Human Resource Management: Implications for Multinational Corporations Operating in the Arab Middle East.
}

\author{
Liza Howe-Walsh* \\ Portsmouth Business School, \\ University of Portsmouth \\ Ricmond Building \\ Portland Street \\ Portsmouth \\ PO1 3DE \\ Liza Howe-Walsh, e-mail: liza.howe-walsh@port.ac.uk \\ Sarah Turnbull \\ Portsmouth Business School, \\ University of Portsmouth \\ Ricmond Building \\ Portland Street \\ Portsmouth \\ PO1 3DE \\ Sarah Turnbull, e-mail: sarah.turnbull@port.ac.uk \\ Aisha Boulanouar \\ Sultan Qaboos University \\ Al Khoudh,Muscat 123 \\ Oman \\ Aisha Boulanouar, e-mail: aishaofnz@gmail.com
}

\begin{abstract}
This paper explores the implications for Human Resources development (HRD) and practice for firms operating in the Arab Middle East. The paper makes two key contributions. Firstly, we expand the current understanding of Islamic axiology and the implications of Islamic ethics in a business context. Second we explore successful expatriation within multinationals within the Arab Middle East. We argue that in addition to the global competencies required by expatriates when undertaking an overseas appointment, firms should also provide training and development opportunities in Islamic ethics in order to facilitate effective business-to-business relationships to aid effective and efficient social networks. The article outlines a conceptual model of the factors influencing the success of expatriate assignments in the Arab Middle East during each stage of an expatriation.
\end{abstract}

Keywords: Islamic Ethics; International Human Resource Management; Expatriates and Middle East. Biographical notes:

Dr Liza Howe-Walsh is a Senior Lecturer in International Human Resources Management and an Associate of the Centre for Strategy and Leadership at the University of Portsmouth. Liza has extensive international HR management and consultancy experience, formerly with PwC LLP covering Europe, Middle East and Africa. She is a thought leader on International HR management and has extensive experience and research in Global Leadership Competencies, global mobility across Europe, Middle East and Americas.

Dr Sarah Turnbull is a Senior Lecturer in Marketing at the University of Portsmouth. Her research interests include Middle East advertising, Islamic brand communications and business-to-business marketing in the Middle East. Prior to her academic career Sarah held senior account management roles in a number of global agencies and spent 8 years working in the Middle East as Account Director on the Emirates Airline account.

Dr Aisha Boulanouar is part of the Department of Marketing at Sultan Qaboos University, Oman and a consultant at Muslim Marketing Matters. She is the Associate Editor of The International Journal of Islamic Marketing and Branding. Aisha has lived in Saudia Arabia, Japan and New Zealand where she studied a PhD in 
Marketing completed at the University of Otago in Dunedin, New Zealand. Aisha's research interests include all aspects of Islamic Marketing, as well as wider issues in Consumer and

Organisational Research.

\section{Introduction}

This paper aims to bridge the gap between previous examinations of cross-cultural management (Adler, 1983; Brannen and Salik, 2000; Tayeb, 1994) and consideration of Islamic ethics (Al Rawi and Ibrahim, 2011; Hosseini, Aidi and Vazirzanjani, 2011; Hutchings and Weir, 2006; Rice, 1999, 2004; Weir and Hutchings, 2005). We develop a framework for Human Resources (HR) expatriate management in the Arab Middle East that considers the importance of social networks to facilitate a more successful expatriate experience.

In order to define expatriate success we refer to Tung's (1987) research which defines a successful expatriation as one where the individual performs effectively in a foreign country and remains for the planned duration. This definition can be developed further to encompass repatriates acknowledging that part of successful expatriation includes retaining the repatriate when they return to the home organisation. Repatriation is noted by scholars to be a time where the expatriate is vulnerable to leaving the organisation, notably up to 49 percent of repatriates leave the organisation within two years of return (Baruch, Steele and Quantrill, 2002; Black and Gregersen, 2007).

We seek to add knowledge to this definition in terms of understanding the role of HR to assist expatriates development in Islamic Ethics. We acknowledge the importance of developing effective and efficient social networks and note the distinction between formal and informal networks (Ibarra, 1993) as well as the influence of diversity (Ibarra, 1993a). We further the theoretical discussion to include social networks and the implications for expatriates (Richardson and McKenna, 2014).

The article has two main contributions. Firstly we discuss the nature of Islamic ethics and the implications that these beliefs and values have for the management of expatriates working in an Islamic environment. Second, we develop a conceptual framework to facilitate a greater understanding of the role of HR during the expatriation process, highlighting the importance of networks to aid successful expatriation. The framework extends beyond the scope of generic international cultural competence models by systematically considering the stages of employee expatriation and related HR activities that would develop a greater understanding of Islamic ethics for expatriates working within in the Arab Middle East. We develop propositions regarding the success of expatriation and the HR activities associated with each stage. As well as providing a useful planning tool for practitioners, the framework intends to provoke current academic debate and inform teaching in cross-cultural management.

\section{Islamic ethics: Components and Implications}


Whilst there is widespread recognition of the importance of firms developing a greater understanding of the cultural context of global markets, there has however been less attention given to the value of developing awareness of Islamic ethics when operating in the Arab Middle East (Rice, 1999; Howe-Walsh, Turnbull, Rayner and Yalari, 2011).

There is extensive acknowledgement that Islam embraces all aspects of social and economic life (Alserhan, 2011; Yusuf, 2010; Branine and Pollard, 2010; Hosseini, Aidi and Vazirzanjani, 2011). Indeed, Yusuf (2010, p.220) argues that "the social life of a Muslim is Islam; the economic life of the Muslim is Islam; the political life of the Muslim is Islam". Therefore firms operating in the Arab Middle East need to understand Islamic ethics in order to be effective. Moreover, global organisations need to provide the necessary skills and knowledge to expatriates undertaking an assignment in such Islamic contexts.

Working within an Islamic ethical framework may reflect outcomes consistent with Western/Biblical ethical frameworks, leading to a belief that Islamic ethics are 'understood' or that they fall into a universal (Christian) ethical framework. This is also true of the definition and purpose of work itself (Ali and AlOwaihan, 2008). Work, like all aspects of human existence, is to "obey and fulfil Allah's commandments and act as the vice-regent [trustee/khalifa] of Allah on earth" (Kazmi, 2005, p.275). Similarly, there are no negative connotations with working or establishing businesses and Muslims are encouraged to take up all (halal/lawful) opportunities (Rice, 1999).

This impression, however, is misplaced. Islam is organically different to Christianity, has different parameters and different requirements, and while there is much overlap in terms of ethical outcomes the starting points and, especially, processes are very different (Davies, 1988, Elmessiri, 2006).

Muslim societies are based on Islamic teaching, just as Western ones are based on Christian teaching, and so the laws, institutions, norms, culture and values reflect that (Charrad, 2001). However, many Muslim countries have been colonised in the recent past, and laws consistent with the former colonisers have been introduced which impact the civil services and, hence, HR (Ali, 2010).

In particular, six dominant ethical dimensions emerge from the literature on Islamic teachings on ethics: Unity (Alserhan, 2011; Rice, 1999; Beekun, 1997); Faith (iman) (Alserhan, 2011); Trusteeship (khalifah) (Alserhan, 2011; Rice, 1999); Balance (Alserhan, 2011; Beekun, 1997); Justice (Adl) (Alserhan, 2011; Rice, 1999; Al Rawi and Ibrahim, 2011; Yusuf, 2010; Branine and Pollard, 2010; Hosseini et al, 2011; Beekun, 1997) and Free will (Alserhan, 2011; Beekun, 1997).

Islam's 'core concept' or at least the first step for understanding Islam and Muslims is that of unity (Tawheed). Tawheed refers to the unity of all creation under one Creator, Allah. All life is unity, and all of life is unity, reflecting the lack of demarcation in Islamic thinking between the religious and non-religious aspects of life. For Muslims there are none of the latter. As a societal concept, it means that people have a responsibility to each other, reflecting a 'horizontal' relationship with Allah. As an individual ('vertical') concept, it means that people have a responsibility to Allah and acknowledge His omnipotence and omnipresence. This last idea, omnipresence, is what separates Muslims from other believers, according to Armstrong (2004). For Muslims, this presence is real, palpable, and means that there is (always) another motivator besides the opinions/impressions of other people to do things (immanence), there is a consideration of transcendence, or a duty to Allah. The unity concept, therefore, governs all business practice from how individuals approach work their individual and collective accountability to the employer, the employees and the wider society.

This overarching concept of transcendence and the omnipresence of Allah relates directly to Islamic ethics in terms of the importance of 'process'. In Islamic teaching a process must be lawful (halal) from inception to completion, so the process must be ethical at all points to be considered ethical at all - in Islamic teaching there is no 'ends justifies the means' concept. Similarly, there is no caveat emptor. So, if your business is involved in the selling of unlawful (haram) goods, or uses unlawful practices, the whole organisation is considered unethical (Beekun, 1996). Or, as Kazmi (2005) puts it, 'The Islamic approach harbours no illusions of relativity in ethics' (p.278).

As Rice (1999) states, 'Islam ... places greater emphasis on duties than on rights' (p.349), so acknowledgement of tawheed acknowledges that society is the primary institution of note (rather than the state). Therefore, businesses are expected to have both economic and on-economic objectives.

The six principles of Islamic ethics delineated by Alserhan (2011) will be individually discussed under the 'umbrella' concept of Tawheed. Following that discussion, each principle will be drawn together to illustrate the interweaving of the concepts within the overall Islamic teaching.

Faith (iman) consists of several separate points of belief in Islamic teaching and has been characterised as the 'intrinsic' (vertical) part of Islamic faith. These are belief in Allah, belief in his Messengers (these begin with Adam, include Moses and Jesus, and end with Mohammed), belief in His Books (including the books revealed to Moses, David, Jesus ${ }^{1}$ and Mohammed (Qur'an), belief in His Angels, the Unseen and Satan, Belief

\footnotetext{
${ }^{1}$ Please note that the Islamic position is that the Book of Jesus (the Injeel) has been altered, and it cannot be represented by the Bible as it is printed today.
} 
in the Day of Judgment and Belief in His Decree (predestination - qadr) - both the (seemingly) good and the (seemingly) bad.

Belief in these things must be absolute, complete. From an Islamic ethics perspective, one element that may be most different/difficult for expatriates, is the concept of predestination (qadr), referred to in everyday Arabic (by Muslims of all native languages) through the use of the phrase "insha'Allah" which means "God Willing" or "If God Wills It". The Islamic understanding of predestination is not a passive one; humans were created with free will and are able to act according to it. However, all things are within the realm of knowledge of Allah, while humankind is limited in knowledge. Hence, 'insha'Allah' acknowledges this limitation and also the aspects of predestination in Islam which promote the flexibility of the decree through a person's supplications (dua'a) and their performance of good deeds. Muslims believe faith increases with obedience to Allah, allowing blessings (baraka) to flow towards the person and/or his/her halal activities.

Trusteeship or khilafah acknowledges that humankind owns nothing - not even their own bodies - but hold everything Allah has given to them as an ammanah (a trust) from Allah, for which they will be accountable on the Day of Judgement. According to Islamic teaching your body will testify to your treatment of it and how you used it during your lifetime - what you did with your hands, what you said with your tongue, what you walked towards, or away from, what you saw or averted your gaze from. In a business context, this trusteeship also extends to resources, which must be lawfully acquired and beneficially redistributed (Alserhan, 2011). Natural resources, such as the sun, the rain, the crops, the water are blessings - a rahma (mercy) - for all humankind (Boulanouar and Boulanouar, 2012). This trusteeship is extended to the position you hold, the treatment you give staff, suppliers and customers and also the impact of production on the environment. Temporal (2011), considers Khalifah 'possibly the most important Islamic value' for business people to grasp (p.238). It offers a different perspective on competition, as it allows precludes: monopolies; hoarding; waste; environmental ruin.

In Islamic teaching 'balance' is struck for an individual through everyone acting for the benefit of the society. In this way, value is emphasised over profit (Saeed, Ahmed and Mukhtar, 2001; Ali, 2013) and societal good over individual benefit. Therefore, Islamic ethics is interested in outcomes that benefit everyone through the cycle of production, and which minimise harm to others, even if that means charging less for a product which all people would benefit from so everyone could have access to it, or choosing not to develop/promote/sell some products which would benefit no-one at all. Consistent with this concept is the point that whatever is Halal (lawful) is sufficient, and whatever is Haram (unlawful) is excessive (Alghorani, 2011). Businesses must be 'socially useful' - dealing fairly in goods and services which benefit the society and all wealth must be productive (Alserhan, 2011; Rice 1999.

Justice reflects the Islamic understanding that with each allocation which may look 'good' or 'bad' in the context of this life from the preordained decree of Allah such as very good looks or very great wealth (seen as ' good') or very great hardship or very great loss (seen as 'bad') the role of the Muslim is to deal with the trial justly. For example, being very very good looking has benefits (Berggren, Jordahl and Poutvaara, 2010), which are commonly discussed in psychology, such as other people think you are more trustworthy, honest and good than people less good looking. The trial for a Muslim with this allocation is to avoid the temptation of using it to their advantage or to the disadvantage of others; to use it to draw attention to injustice or cruelty; to be aware that they will be answerable on the last day for the allocation and how they dealt with it. In a business context, justice requires the eradication of injustice, oppression and exploitation. It requires economics to be integrated with ethics (Naqvi, 1981).

Free Will All humankind has been created with free will. This free will, like human knowledge referred to above, is bounded between the bookends of what is compelled. For example, no-one has free choice over when or where or to whom he or she is born, but you are free to live your life as you see fit; all humankind must eat, but what you eat is a matter of choice - a format for the expression of free will. Muslims who act outside of the Islamic teaching are seen as 'disobedient'. Disobedience of a believer is quite different from disbelief in the Creator. Muslims believe that all human beings are born as Muslims and are then raised either as Muslims or have their views alternatively shaped by their parents. Regardless of how they are raised, Muslims believe all humankind has contracted a covenant with Allah, whether they are aware of it or not. The choice between belief and disbelief is the most important choice a human being will make. The free will that Allah has allowed humankind attracts accountability, and that responsibility means that Muslims are required to deal responsibly with other people. Islamic ethics expects an internal locus of control in Muslims, and advocates individual accountability for all people, not just the CEO or manager. It also see the motivation to work as feeding an internal function first, and a material function second. This idea could be illustrated as an inversion of Maslows hierarchy, where the higher level needs are met first, and the basic needs second (Kazmi, 2005). The reason for this inversion is that all (halal) acts are considered a form of worship (ibadah) for Muslims (Siddiqui, 1982; Rice, 1999). 
The six concepts that make up an overview of Islamic ethics are disparate and intertwined, consistent with the overarching concept of unity (Tawheed). For example, the practice of hiring family members or relatives, even when they are possibly not technically well qualified for the role, is commonplace in the Muslim world. While often viewed very sternly as nepotism, it is practiced as a cultural 'derivative' of unity. Family are loyal, permanent, long-term employees and can have have their educational shortfalls updated over time (Brislin, 2008). This collectivity also strongly influences business relationships, which are build slowly and based on trust and friendship. Brislin (2008) echoes Rice, stating that in a collectivist context there are three categories of interactions: 1) people don't know each other and interactions can be formal and "stand off-ish"; 2) people have little to do with each other or know each other but do not yet have collectivist ties. Interactions tend to be polite and involve complex etiquette; and, 3) they know each other long and well and planned politeness need not be so carefully observed. At this point relationships are often robust, direct and honest, as they are regarded as permanent. Muslims vary in their practice of Islam, but Islamic teaching is consistent in its message on everything that affects life, and ethical business practice is no exception. An observant Muslim will do his or her utmost to exercise their free will in a way that is halal (lawful) and will endeavour to treat all people in a balanced, fair, just and lawful way consistent with their faith and their understanding of the trusteeship they have in their various life roles.

\section{Implications for managing business relationships in Gulf Cooperation Council (GCC) countries.}

Relationships are important in all business interactions, but for Arabs, particularly, face to face interactions, communications and personal relationships are especially significant (Torstrick and Faier, 2009, Tuncalp, 1988; Alhersan, 2011). Several authors have highlighted the importance of informal networks in the Arab Middle East (Hutchings and Weir, 2006; Metcalfe, 2007). Weir and Hutchings (2005) argue that these networks are culturally embedded in the Arab world and as such are an intrinsic aspect of business exchange in the region (Weir and Hutchings, 2005). Personal relationships lie at the heart of these networks as Hutchings and Weir (2006, p.277) examine, 'the basic rule of business in the Arab World is to establish a relationship first, build connections, and only actually come to the heart of the intended business at a later meeting'. There is therefore an implicit understanding that without a personal relationship, it is unlikely that a business relationship will develop. Hence for multinationals to operate successfully in the Arab Middle East the company needs to provide their expatriate employees with the competencies and knowledge to be able to develop social networks to aid business relationships.

A good understanding of Islamic axiology and the resulting ethical framework we argue could only enhance management of relationships within a Muslim context. As Muslims subscribe to a doctrine of unity (Tawheed) as outlined above, every interaction is related to all others and must be guided by a consideration of their responsibilities to Allah directly (the 'vertical' relationship) as well as to other people (the 'horizontal' relationship) - both relationships being measured and answerable for, in the framework of Islamic teaching (Boulanouar, 2006). Muslim colleagues or business contacts then, spend much time getting to know people. Consistent with the high context culture of the Arabs (Hall, 1976) and their native language, much talk would necessarily seem completely unconcerned with the business at hand or, indeed, the business at all, but of a more personal nature (Tuncalp, 1988, Alhersan, 2011). This is because, as Al Faruqi states, "The Islamic view ...affirms society as the realm for the actualisation of the highest ethical values; and it regards societal action as such, as embodiment of a higher order of moral existence" (p.163). Further, he states "Ethical values require the existence of others, interaction with them, and conditions under which there are needs to which the moral subject responds if ethical action is to take place... Islamic morality is essentially an ethic of action" (p.164).

As mentioned above, Muslims vary in their practice of Islam, with some, for example, 'taking a prayer break...no matter how important the issue being discussed or the stage of the discussions' (Alserhan, p.15), while others are less observant. However, and despite the acknowledged 'gap' between Islamic teaching on ethics and the observed practice in much of the Muslim world (for example, Abuznaid, 2009; Rice, 1999; Bouma et al, 2003) several points must be remembered. As also mentioned above, there is a great difference between disobedience and disbelief. Rice (1999) recommends that respect is always shown for Islam, because even the disobedient believe Islam to be the truth. She also recommends that ex-pats consider the reasons for deviations between what is taught in Islam and what is observed in the field. Ali (1992) gives an extensive account of this, ranging from a campaign of psychological inferiority by colonial powers to artificial division of Arab lands to an over concern of Arab governments with their own political security. Knowledge of 'the Islamic ideal is part of a universal Islamic culture, common to all Muslims around the world' (Rice 1999, p. 356) and, hence, is an essential framework to understand in a business context.

\section{HR Strategies For Cross-Border Management}


Whilst scholars have identified the need for firms operating in such States to develop both a greater cultural awareness and knowledge of Islamic ethics (Al Rawi and Ibrahim, 2011; Hosseini et al, 2011; Hutchings and Weir, 2006; Rice, 1999, 2004; Weir and Hutchings, 2005), to date there has been limited attention given to the HR policies and practices that can support this (Bouma et al. 2003).

HR scholars acknowledge that developing human resource practices that attract, retain and develop global workers can provide a global competitive advantage to firms (Bartlett and Ghoshal, 1994, 1995; Ghosal and Bartlett, 1997; Richardson and McKenna, 2014). Therefore it seems apposite to consider the HR strategies that would facilitate the development of skills in expatriate employees to operate in an Islamic context such as in the Arab Middle East.

Existing research on HR practice identifies three distinctive stages that Multi-National Corporations (MNCs) consider when planning international assignments: pre-departure phase (recruitment and selection); ongoing assignment activities (support) and final stage repatriation (Bonache, Brewster, and Suutari, 2001; Harzing and Christensen, 2004). This paper explores each of these three stages of expatriation and considers how HR can facilitate the development and understanding of Islamic ethics throughout the expatriate assignment.

\section{INSERT FIGURE 1 HERE}

\subsection{Pre Departure Stage 1}

\subsubsection{Recruitment and Selection}

Firstly we consider the pre-departure phase and the role of recruitment and selection process. Recruitment refers to attracting qualified candidates for the international assignment. Selection refers to the process of selecting the final candidate. International Human Resources Management (IHRM) scholars recognise the value of effective recruitment and selection for overseas assignments and acknowledge the importance and complexity of this stage to the overall success of international assignments (Black and Gregersen, 2007; Caliguri, Tarique and Jacobs, 2009; Harris and Brewster, 1999; Sparrow, 2007; Tung, 1981).

One of the issues identified within the literature is that informal recruitment and selection procedures are favoured by line managers (Harris and Brewster, 1999). The capability of the individual in terms of the cultural sensitivity may not form part of the recruitment and selection process. Thus when a candidate is selected internally, the HR department have to ensure that the candidate has been selected to meet the essential criteria for the role to enable them to perform effectively in an overseas location. In contrast external recruitment and selection may follow a formal HR process. However, this may still not ensure that HR considers the cultural competence of the individual. This may be particularly pertinent when considering expatriate assignments in the Arab Middle East.

Selection based upon competencies to predict adjustment to another culture is the focus of much of the (IHRM) literature (Black, Gregersen and Mendenhall, 1992; Caliguri, 2000; Engle, Mendenhall, Powers and Stedham, 2001; Liu and Shaffer, 2005; Sparrow, 2007). Whilst there is debate surrounding the specific traits that predict an individual's ability to perform effectively in cross-cultural contexts and more specifically the constructs of global competencies, several authors have offered a range of typologies to develop global leaders (Bronwell, 2006; Conner, 2000; Jokinen, 2005; Mendenhall, 2006). Identifying global competencies is often explored via an inventory to score an individual's competence (Caliguiri, 2000; Harvey and Novicevic, 2006; Vance, 2005).

Olson and Kroeger (2001:118) define globally competent individuals as having the following attributes: substantive knowledge (knowledge of cultures, languages, world issues); perceptual understanding (open mindedness, resistance to stereotyping, complexity of thinking); and intercultural communication skills (adaptability, empathy, cross cultural awareness, intercultural relations, cultural mediation) to effectively interact globally. We consequently propose that:

Proposition 1: The selection of expatriate employees with high levels of global competencies will be positively associated with successful expatriate assignments in the Arab Middle East.

\subsubsection{Pre-departure briefing}

Scholars have also identified the value of pre-departure briefings for international assignees (Black, Mendenhall and Oddou, 1991; Caliguri and Tarique, 2006; Hutchings and Weir, 2006; Wang and Tran, 2012). Preparation of the expatriate traditionally facilitated by HR is often cited as including cross cultural briefing, language training; terms of employment; financial compensation etc. (see Williams, Howe-Walsh and Scott 2013: 328, for a review of supporting activities).

Pre-departure training offers an insight into setting expectations of the expatriate which is often cited as crucial in successful adjustment of the individual (Black et al, 1991). It is noted that providing an opportunity 
to visit the assignment location to provide a realistic preview of the country should form part of pre-departure activities (Caliguri and Tarique, 2006; Williams et al, 2013). Thus setting expectations and increasing the likelihood of adjustment is aided by understanding other considerations when deciding to work internationally. This is particularly prevalent when considering expatriates accompanying partner and family (Larsen, 2006). Consideration regarding continuity of education for children, partners career etc. will impact upon the decision to expatriate. As too will the health of the expatriate and their family which is where health screening prior to assignment is advantageous (Briscoe, Schuler and Tarique, 2012).

Exploring what makes an individual more likely to undertake an assignment can assist HR to develop appropriate HR activities. The link between receptivity towards an overseas experience and the desire to work in an overseas location has been the subject of Tharenou's research, (2002; 2003). Tharenou (2002) contends that by providing employees with a supportive environment individuals are more likely to undertake an overseas experience. Her research highlights that the support offered by HR enhances the receptiveness towards an international experience; this is useful to understand in the context of the Arab Middle East. Perceptions of what it might be like to work in such a context can be explored in advance of the expatriation. Cross cultural training is essential and acknowledged as a key component to aid the expatriate's adjustment to their host location (Schneider and Barsoux, 2003; Shi and Franklin, 2013; Waxin and Panaccio, 2005) and is seen as specialist training often undertaken by an outsourced provider (Teagarden and Von Glinow, 1997).

Whilst the Human Resource function is not only challenged to identify acceptable business practices in an Islamic context specific to the region, further clarity surrounding a factual briefing in order to carry out their day- to-day role is also required to develop cultural awareness (Black et al, 1991; Bouma et al. 2003; Holopainen and Björkman, 2005; Napier and Hoang, 2011; Tharenou, 2003). The scenario provides an opportunity for HR to add value (Bossard and Peterson, 2005; Lazarova and Cerdin, 2007) sequencing preassignment briefing activities as well as identifying the current global competencies that an individual displays. At this stage the importance of developing and maintain home and host social networks are critical and can be supported by the HR function.

In addition, it is advisable to extend this deeper level of understanding of the environmental context to accompanying members of the family. Family barriers to successful expatriation are noted by several authors as the main reason for failure of the assignment (Larson, 2006; Tharenou, 2003). Support for not only the expatriate but the accompanying family could be considered and can be aided through the HR function (Shaffer, Harrison, Gilley, and Luk, 2001; Suutari and Burch, 2001). Richardson and Zikic (2007, p.170) have developed a useful set of recommendations to consider such as aiding accompanying spouses to find appropriate employment. This may be supported by HR practices that provide assistance to establish realistic living conditions through pre-departure house hunting trip. A preview of the overseas location can also aid expectations by providing support to find employment for any accompanying partner. In addition this trip can develop non work related assistance such as forming social networks, i.e. the local community, expatriate community, social and sports amenities, etc. Moreover, grounded expectations of the cultural differences can be explored including those relating to the six touchstones of Islamic ethics - Unity; Iman (faith); Khilafah (trusteeship); Balance; Adl or Justice; Free will.

To date there has been no exploration of the value of Islamic ethical training/development for assignments in the Arab Middle East. Moreover, in addition to developing cultural knowledge of the particular market, training provides an opportunity to develop a deeper understanding of Islamic Ethics. Providing knowledge for example of how the six touchstones are operationalised in everyday business transactions and behaviour will enable expatriates to empathise with the cultural context in which they conduct business. Thus, we propose pre-departure training in Islamic Ethics is a prerequisite to an international assignment. We consequently argue:

Proposition 2: The implementation of pre-departure training in Islamic ethics, along with the development of home and host social networks will be positively associated with successful expatriate assignments in the Arab Middle East.

\subsection{ON GOING, STAGE 2}

During an expatriation, further support from HR can be required on an ongoing basis; HR can add value to the experience through continued support (Richardson and Zicki, 2007). In order to develop support much of the previous research recognises the importance of coaching and mentoring arrangements (Brewster, Sparrow and Vernon, 2007; Lazarova and Caliguri, 2001). Arguably assigning a sponsor in the home location provides a mechanism for the expatriate to maintain contact and interest in the home organisation which is useful for planning the repatriation (Jassawalla, Connolly and Slojkowski, 2004). HR has a role in initiating mentoring and sponsorship arrangements which can be formalised as part of the terms and conditions of an assignment (contract of employment). 
Previous research has also highlighted the importance of formal and informal networks (Suutari and Burch, 2001) to support the early stages of expatriation. HR can help facilitate the development of informal social networks in conjunction with work related networks leading to adjustment to working overseas, and importantly support networks to develop business relationships (Howe-Walsh and Schyns, 2010; Richardson and McKenna, 2014). This is particularly relevant to consider in the Arab world where networks are a culturally embedded aspect of society and business activity (Weir and Hutchings, 2005).

Understanding local customs and language training also form part of the ongoing activities (Black and Mendenall, 1990; Waxin and Panaccio, 2005). In addition assistance to develop knowledge of practical issues such as the local rules and regulations to drive, undertake a tax return etc. have value to the individual and thus coordinating these activities can aid the success of the international assignment through a concerted set of practices co-ordinated by HR (Lazarova and Cerdin, 2007).

In order to support training during the expatriation the role of a mentor has been highlighted to aid the expatriation experience (Mezias and Scandura, 2005). The role of the mentor is noted to provide support in terms of information and social support. Carraher, Sullivan and Crocitto (2008) research involving 299 expatriates found that a host country mentor had a positive effect upon organisational knowledge and knowledge sharing as well as the expatriates performance and career development opportunities. Moreover they found that the mentor has a positive significance upon team work. This leads us to the following propositions:

Proposition 3a): HR support to address formal social networking opportunities will aid successful expatriation to the Arab Middle East.

Proposition 3b): HR support to address informal social networking opportunities will aid successful expatriation to the Arab Middle East.

Proposition 3c): The implementation of Islamic ethics training during the on-going stage will be positively associated with successful expatriate assignments in the Arab Middle East.

Proposition 3d): HR support to facilitate a host country mentor within the organisation will enhance the expatriate experience in the Arab Middle East.

\subsection{REPATRIATION, STAGE 3}

Planned repatriation activities are noted by several authors as an essential element in aiding retention of the expatriate (Baruch et al, 2002; Howe-Walsh, 2010; Hyder and Lovblad, 2007; Lazarova and Cerdin, 2007; Ratiu, Lvina and Berte, 2011). The return home can be more difficult than the original move (Briscoe et al, 2012). Often the expatriation has provided greater career autonomy and challenge. The return to a position that does not hold the same challenge and degree of challenge experienced during the assignment can cause the expatriate to feel unsatisfied (Sanchez Vidal, Sanz Valle, Bara Aragon, 2007). Repatriation is noted to be a key turning point in the expatriates' career, thus they are vulnerable to leaving the organisation.

The HR function can add value by providing support to plan for succession and aid continuity of a business relationship. Expatriates pose unique opportunities that challenge the business to find a return position to benefit the company and the individual (Howe-Walsh, 2011). Activities such as debriefing the repatriate are a useful source of future information for the organisation to gauge global competencies valued for international work. In addition the organisation needs to ensure that any implicit knowledge is transferred to the new individual. More importantly planned repatriation activities arguably aid retention of the expatriate (Kraimer and Wayne, 2004; Lazarova and Cerdin, 2007). Therefore, we propose:

Proposition 4a): Planned repatriation activities involving social networks with the home organisation will be positively related to successful expatriate assignments in the Arab Middle East.

Proposition 4b): Planned repatriation activities will enable transfer of knowledge including Islamic ethics related to working within the Arab Middle East.

\section{CONCLUDING COMMENTS}

The Arab Middle East presents a complex business context for multinationals and their expatriate employees to operate within. We suggest that expatriates would benefit from an understanding of Islamic axiology and highlight in particular the six touchstones of Islamic ethics - Unity; Iman (faith); Khilafah (trusteeship); Balance; Adl or Justice; Free will. Developing social networks is part of the support that the organisation can proactively facilitate to aid adjustment. We extend current knowledge by considering the HR engagement to facilitate this deeper understanding of Islamic ethics and provide a conceptual framework of HR activities.

This systematic approach to each stage of employee expatriation highlights the key HR activities required for a successful expatriate assignment in the Arab Middle East. In particular we propose the selection of candidates who have the competencies to operate effectively in other cultures requires HR engagement activities and suggest that Islamic ethics training would be desirable at both the pre-departure and on-going 
stages. In addition we argue that the facilitation by HR of formal and informal social networking in the host country would have a significant positive impact upon the expatriate's experience. Moreover, we suggest that a host country mentor can aid the development of such networking opportunities as well as aid the expatriates' performance. Lastly we highlight the importance of planned repatriation activities to ensure continuity of knowledge gained during the expatriation as well as transfer of such knowledge to the next job holder. It is hoped that the framework offered will form the basis of further discussion and qualification to deepen academic understanding of Islamic Ethics during expatriation within the Arab Middle East as well as facilitate further research.

\section{References}

Abuznaid, (2009) 'Business ethics in Islam: the glaring gap in practice', International Journal of Islamic and Middle Eastern Finance and Management,2(4), pp.278-288.

Adler, N. J. (1983) 'Cross Cultural Management Research: The Ostrich and the Trend', Academy of Management Review, Vol. 8, No. 2, pp.226-232.

Alghorani, M. A. (2011) 'Islamic Business Ethics', Global Islamic Marketing Conference. Dubai, UAE.

Ali, A. J. (2010) 'Islamic challenges to HR in modern organizations' Personnel Review, Vol. 39, pp.692-711.

Ali, A. J. and Al-Owaihan, A. (2008) 'Islamic work ethic: a critical review', Cross Cultural Management: An International Journal, Vol. 15, pp.5-19.Ali, A J (1992), 'The Islamic Work Ethic in Arabia' Journal of Psychology, Vol. 126 (5).

Ali, A. J., Al-Aali, A., \& Al-Owaihan, A. (2013) 'Islamic perspectives on profit maximization', Journal of business ethics, 117(3), pp.467-475.

AL FARQUi, I. (1987) 'Islam as culture and civilization', in Azzam, S. (Ed.) Islam and Contemporary Society London, Islamic Council of Europe, Longman.

Al Rawi, K. and Ibrahim, M. (2011) 'Islamic Ethics in the Business environments" Paper presented at Global Islamic Marketing Conference, Dubai.

Alserhan, B.A. (2011) 'The Principles of Islamic Marketing'. Farnham: Gower.

Arham, M. (2010) 'Islamic perspectives on marketing', Journal of Islamic Marketing, 1(2), pp.149-164.

Armstrong, K. (2004) 'A History of God: The 4000-year quest of Judaism, Christianity and Islam', NY: USA, Ballantine Books.

Bartlett, C. and Ghoshal, S. (1994) 'Changing the role of top management: beyond strategy to purpose', Harvard Business Review, Vol. 72, No. 6, pp.79-88.

Bartlett, C.A., and Ghoshal, S. (1995) 'Changing the role of top management: beyond structure to process', Harvard Business Review, Vol. 73, No. 1, pp.86-93.

Baruch, Y., Steele, D. J. and Quantrill, G.A. (2002) 'Management of expatriation and repatriation for novice global player', International Journal of Manpower, Vol. 23 No. 7, pp.659-671.

Beekun, R. I. (1997). Islamic business ethics. IslamKotob.Bennett, J.M. (1993) 'Berggren, N., Jordahl, H., and Poutvaara, P. (2010) 'The looks of a winner: Beauty and electoral success', Journal of Public Economics, Vol. 94, pp.8-15.

Black, J. S., Mendenhall, M. E, and Oddou, G. (1991) 'Toward a comprehensive model of international adjustment: An integration of multiple theoretical perspectives', Academy of Management Review, 16 (2): pp.291-317.

Black, J., S, Gregersen, H. B., and Mendenhall, M. E. (1992) 'Toward a theoretical framework of repatriation adjustment', Journal of International Business Studies, Vol. 23, No.4, pp.737-760.

Black, J., S. and Gregersen, H. B. (2007) 'The right way to manage expats', In Mendenhall, M, E., Oddou, G. R., and Stahl, G.R. (Ed.), Readings and Cases in International Human Resource Management pp.119128. $4^{\text {th }}$ Ed. New York: Routledge.

Black, J. S. Stewart, Mark Mendenhall. (1990) 'Cross-Cultural Training Effectiveness: A Review and a Theoretical Framework for Future Research’, Academy of Management Review, Vol.15, pp.113-136.

Bonache, J., Brewster, C. and Suutari, V. (2001) 'Expatriation: a developing research agenda', Thunderbird International Business Review, Vol. 43, No.1, pp.3-20.

Boulanouar, A. W. (2006) 'The Notion of Modesty in Muslim Women's Clothing: An Islamic Point of View', New Zealand Journal of Asian Studies, 8, pp.134-156.

Boulanouar, A. W. and Boulanouar, Z. (2012) 'An Initiation Into The Place and Positioning of Goods and Services in Islamic Marketing', Global Islamic Marketing Conference 2. Abu Dhabi, UAE.

Boselie, P., Brewster, C. and Paauwe, J. (2009) 'In search of balance: Managing the dualities of HRM', Personnel Review, Vol. 38, No.5, pp.461-471. 
Bossard, A. and Peterson, R.B. (2005) 'The repatriate experience as seen by American expatriates', Journal of World Business, Vol. 40, pp.9-28.

Bouma, G., Haidar, A., Nyland, C. and Smith, W. (2003) 'Work, religious diversity and Islam', Asia Pacific Journal of Human Resources, Vol. 41, No.1, pp.51- 61.

Branine, M.and Pollard, D. (2010) 'Human resource management with Islamic management principles. A dialectic for a reverse diffusion in management', Personnel Review, Vol. 39, No. 6, pp.712-727.

Brannen, M. Y. and Salik, J. E. (2000) 'Partnering across borders: Negotiating organisational culture in a German-Japanese joint venture', Human Relations, Vol. 53, No. 4, pp.451-487.

Brewster, C., Sparrow, P. and Vernon, G. (2007) 'International Human Resource Management, London: CIPD.

Briscoe, D., Schuler, R., and Tarique, I. (2012) 'International Human Resource Management', 4e London: Routledge.

Brislin, R,. (2008) 'Working with cultural differences: Dealing effectively with diversity in the workplace'. Westport, CN: Greenwood.

Bronwell, J. (2006) 'Meeting the competency needs of global leaders: A partnership approach', Human Resource Management, Vol. 43 No, 3 pp.309-336.

Caligiuri, P.M. (2000) 'Selecting expatriates for personality characteristics: A moderating effect of personality on the relationship between host national contact and cross-cultural adjustment', Management International Review, Vol. 40, No. 1, pp.61-80.

Caligiuri, P.M. and Tarique, I.: 2006, 'Predicting effectiveness in global leadership activities', Journal of World Business, Vol. 44, pp.336-346,

Caligiuri, P.M., Tarique, I, and Jacobs (2009) 'Selection for International Assignments', Human Resource Management Review, Vol. 19, pp.251-262.

Carraher, S.C., Sullivan, S. E, and Crocitto, M. (2008) 'Mentoring across global boundaries: an empirical examination of home and host country mentors on expatriate career outcomes', Journal of International Business Studies, Vol. 39, pp.1310-1326.

Charrad, M. (2001) 'States and Women's Rights: The Making of Postcolonial Tunisia, Algeria, and Morocco', University of California Press.

Conner, J. (2000) 'Developing global leaders of tomorrow', Human Resource Management, Vol. 39 No. 2/3, pp.147-57.

Davies, M. W. (1988) 'Knowing One Another: Shaping an Islamic Anthropology', Mansell.

Dowling, P.J., Festing M, and Engle, A. (2013). International Human Resource Management. $6^{\text {th }}$ Edition. London: Cengage Learning EMEA.

Elmessiri, A. M. (2006) 'Epistemological Bias in the Physical and Social Sciences', International Institute of Islamic Thought.

Engle, A.D., Mendenhall, M.R., Powers, R.L., and Stedham, Y. (2001) 'Conceptualizing the global competency cube: a transnational model of human resource', Journal of European Industrial Training, Vol. 25, No. 7, pp.346-353.

Ghoshal, S. and Bartlett, C. (1997) 'The myth of the generic manager: new resource competencies for management roles', California Management Review, Vol. 40 No. 1, pp. 92-107.

Hall, E. (1976) 'Beyond Culture', NY:USA, Doubleday.

Harris, H. and Brewster, C. (1999) 'The coffee-machine system: how international selection really works', The International Journal of Human Resource Management. Vol. 10, No. 3, pp.488-500.

Harvey, M. and Novicevic, M. (2001) 'Selecting expatriates for increasingly complex global assignments', Career Development International. Vol. 6, No. 2, pp.69 -86.

Harvey, M. and Novicevic, M. (2006) 'The Evolution from repatriation of managers in MNEs to 'patriation' in global organisations', In Stahl, G., and Björkman. I. (Eds) Handbook of Research in International Human Resource Management. 323-343. Cheltenham: Edward Elgar.

Harzing, A-W. and Christensen, C. (2004) 'Expatriate failure: time to abandon the concept?', Career Development International. Vol. 9, No. 7, pp.616-626.

Holopainen, J. and Björkman, I. (2005) 'The Personal Characteristics of the Successful Expatriate: A Critical Review of the Literature and an Empirical Investigation' Personnel Review, Vol. 34, pp.37-50.

Hosseini, M. H., Aidi, F. and Vazirzanjani, H, R. (2011) 'Developing an Islamic principles-based marketing model (3T)’ Paper presented at Global Islamic Marketing Conference, Dubai.

Howe-Walsh, L. (2010) 'The road to repatriation: implications for HR policy and practice', $\mathrm{PhD}$ thesis, University of Portsmouth.

Howe-Walsh, L. and Schyns, B. (2010) 'Self-initiated expatriation: Implications for HRM', International Journal of Human Resources Management. Vol. 21, pp.260-273.

Howe-Walsh. L., Turnbull, S., Rayner, C. and Yalari, A. (2011) 'Business-to-business relationships in Islamic markets: How can HR add value?’ Global Islamic Marketing Conference. Dubai, March 20-22, 2011. 
Hyder, A S. and Lovblad, M. (2007) 'The repatriation process - a realistic approach', Career Development International, Vol. 12, No. 3 pp.264-281.

Ibarra, H. (1993) 'Network centrality, power, and innovation involvement: Determinants of technical and administrative roles', Academy of Management Journal, 36(3), 471-501.

Ibarra, H. (1993,a) 'Personal networks of women and minorities in management: A conceptual framework', Academy of management Review, 18(1), 56-87.

Hutchings, K. and Weir, D. (2006) 'Guanxi and Wasta: A Comparison', Thunderbird International Business Review, Vol. 48, No1, pp.141-156.

Jasswalla, A. Connolly, T, and Slojkowski, (2004) 'Issues of effective repatriation model and management implications', Advanced Management Journal, Vol. 12, No. 3, pp.264-281.

Jokinen, T. (2005) 'Global leadership competencies: a review and discussion' Journal of European Industrial Training, Vol. 29, No. 3, pp.199-216.

Kazmi, A. (2005) 'Probable differences among the paradigms governing conventional and Islamic approaches to management', International Journal of Management Concepts and Philosophy, 1(4), pp. 263-289

Kraimer, M., and Wayne, S. (2004) 'An examination of perceived organisational support as a multidimensional construct in the context of expatriate assignment', Journal of Management Studies, Vol. 30, No. 2, pp.209- 237.

Larson, D. (2006) 'Here we go again: how a family's cross-cultural and repatriation adjustment: relates to the employee's receptivity to future international assignments', Society for Advanced Journal of Management, Vol. 71, No. 2 pp.46-57.

Lazarova, M., B and Caligiuri, P. (2001) 'Retaining Repatriates: The role of organisational support, Journal of World Business, pp.389-401.

Lazarova, M., B. and Cerdin, J-L. (2007) 'Revisiting Repatriation', Journal of International Business Studies, Vol. 38, pp.404-429.

Lazarova, M. and Tarique, I. (2005) 'Knowledge transfer upon repatriation' Journal of World Business, Vol. 40, pp.361-373.

Liu, X., \& Shaffer, M. A. (2005) 'An Investigation of Expatriate Adjustment and Performance A Social Capital Perspective', International Journal of Cross Cultural Management, 5(3), pp.235-254.

Maude, B. (2011) 'Managing Cross-Cultural Communication: Principles and Practice', London: Palgrave.

Mellahi, K. and Budhwar, P, S. (2010) 'Introduction: Islam and Human Resource Management', Personnel Review, Vol. 39, No. 6, pp.685-691.

Mendenhall, M.(2006) 'The Elusive, yet Critical Challenge of Developing Global Leaders'. European Management Journal, Vol. 24, No. 6, pp.422-429

Metcalf, B. D. (2007) 'Gender and human resource management in the Middle East', International Journal of Human Resource Management, Vol. 18 No.1, pp.54 - 74.

Mezias, J. M., and Scandura, T. A. (2005) 'A needs-driven approach to expatriate adjustment and career development: A multiple mentoring perspective', Journal of International Business Studies, Vol. 36, No. 5, pp.519-538.

Napier, N. K., \& Hoang, V. Q. (2011). Getting to the real story: what Vietnamese business people wish foreigners understood about doing business in emerging and transition countries like Vietnam-before they start. International Journal of Human Resources Development and Management, 11(2), pp.208220.

Naqvi, S. N. H. (1981). Ethics and economics: An Islamic synthesis (Vol. 2). London: islamic foundation.Olson, C. L., and Kroeger, K. R. (2001) 'Global competency and intercultural sensitivity', Journal of Studies in International Education, Vol. 5, pp.116-137.

Ratiu, C., Lvina, E., \& Berte, E. (2011). Matchmaking and the multinational enterprise: how individual motivation and international strategy interact to affect expatriate adjustment. International Journal of Human Resources Development and Management, 11(2), pp.274-289.

Rice, G. (1999) 'Islamic Ethics and the implications for business', Journal of Business Ethics, Vol. 18, No. 4, pp.345-358.

Richardson, J.J. Zikic.2007, The darker side of an international academic career. Career Development International'2,164186Richardson, J., \& McKenna, S. (2014) 'Towards an understanding of social networks among organizational self-initiated expatriates: a qualitative case study of a professional services firm', The International Journal of Human Resource Management, (ahead-of-print), 1-17.

Saeed, M., Ahmed, Z. U. and Mukhtar, S.-M. (2001) 'International Marketing Ethics from an Islamic Perspective: A Value-Maximization Approach', Journal of Business Ethics, Vol. 32, pp.127-142.

Sanchez Vidal, M, E., Sanz Valle, R., and Bara Aragon, M., I. (2007) ‘Antecedents of repatriates' job satisfaction and its influence on turnover intentions: Evidence from Spanish repatriated managers', Journal of Business Research. Vol. 60, pp.1272-1281.

Schneider, S.,C. and Barsoux, J-L. (2003) 'Managing Across Cultures', Prentice Hall: London. 
Shapiro, J, M. Ozanne, J, L. and Saatcioglu, B. (2008), 'An interpretive examination of the development of cultural sensitivity in international business’, Journal of International Business Studies. Vol. 39, pp.71-87.

Shaffer, M., A., Harrison, D. A., Gilley, M. K. and Luk, D. M.( 2001) 'Struggling for balance amid turbulence on international assignments: work-family conflict, support and commitment', Journal of Management, Vol. 2, No. 27, pp.99 - 121.

Shi, X., \& Franklin, P. (2013) 'Business expatriates' cross-cultural adaptation and their job performance', Asia Pacific Journal of Human Resources. DOI: 10.1111/1744-7941.12003

Siddiqi, M. N. (1981). Muslim economic thinking: a survey of contemporary literature (Vol. 1). International Centre for Research in Islamic Economics, King Abdul Aziz University.Sparrow, P. R. (2007).

'Globalisation of HR at function level: four UK based case studies of the international recruitment and selection process', The International Journal of Human Resource Management, Vol. 5 No.18, pp.845867.

Suutari, V. and Burch, D. (2001) 'The role of on-site training and support in expatriation: Existing and necessary host-company practices', Career Development International, Vol. 6, 298-311.

Organization Studies, Vol. 15, pp.429-445.

Teagarden, M. B. and Von Glinow, M, A. (1997) 'Human resource management in cross-cultural contexts: emic practices versus etic philosophies’, Management International Review, Vol. 37, pp.7-20.

Tharenou, P. (2002) 'Receptivity to career in international work - abroad and at home Australian', Journal of Management, Vol 2, pp.129-136.

Tharenou, P. (2003) 'The initial development of receptivity to working abroad: Self-initiated international work opportunities in young graduate employees', Journal of Occupational and Organisational Psychology. Vol. 76, pp.489- 515 .

Torstrick, R. L. and Faier, E. (2009) 'Culture and Customs of the Arab Gulf States', Greenwood Pub Group.

Tuncalp, S. (1988), 'The marketing research scene in Saudi Arabia', European Journal of Marketing, Vol. 22, pp.15-22.

Tung, R. (1981) 'Selection and training of personnel overseas assignments', Columbia Journal of World Business, Vol. 16, No.1, pp.68-78.

Tung, R.L.: (1982) 'Expatriate Assignments: Enhancing Success and Minimizing Failure', Academy of Management Executive, Vol. 1, No. 2, pp.117-125.

Vance, C.M. (2005) 'The personal quest for building global competence: A taxonomy of self initiating career path strategies for gaining business experience abroad', Journal of World Business, Vol. 40, pp.374 385.

Wang, Y. L., \& Tran, E. (2012) 'Effects of cross-cultural and language training on expatriates' adjustment and job performance in Vietnam', Asia Pacific Journal of Human Resources, Vol. 50, No. 3, pp.327-350.

Waxin, M-F. and Panaccio, A. (2005) 'Cross-cultural training to facilitate expatriate adjustment: it works!', Personnel Review, Vol. 34, No. 1, pp.51 - 67.

Weir, D. and Hutchings, K (2005) 'Cultural filtering in the Arab World and China: Exploring the interrelationship of the technological knowledge age and traditional cultural networking and interpersonal connections' In World Wide Work, Ed. S.G.M. van de Bunt-Kokhuis and M. Bolger, Free University of the Netherlands, The Hague.

Williams, S. Howe-Walsh, L., J., and Scott, P. (2013) International Human Resource Management in Practice. Williams, S. and Gilmore, S. Human Resource Management in Practice. (Ed) Oxford: Oxford University Press. Yusuf, J. B: 2010, 'Ethical implications of sales promotion in Ghana: Islamic perspective', Journal of Islamic Marketing, Vol. 1, No. 3 pp.220-230. 
Fig 1. Conceptual framework of HR activities for expatriation in the Arab Middle East

\section{Pre-departure Stage 1}

P1 Global competencies

P2 Islamic ethics training

On going Stage 2

P3 a) Formal networking

P3 b) Informal networking

P3 c) Continued Islamic ethics training

P3 d) Host country mentor

\section{Repatriation Stage 3}

P4a) Planned repatriation

P4b) Knowledge transfer
Success of expatriation in the Arab Middle East

Completion of assignment

$>$ Retention of employee

$>$ Retention of knowledge Knowledge transfer 